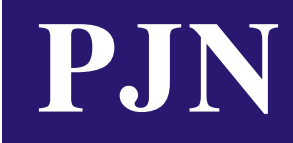

ISSN 1680-5194

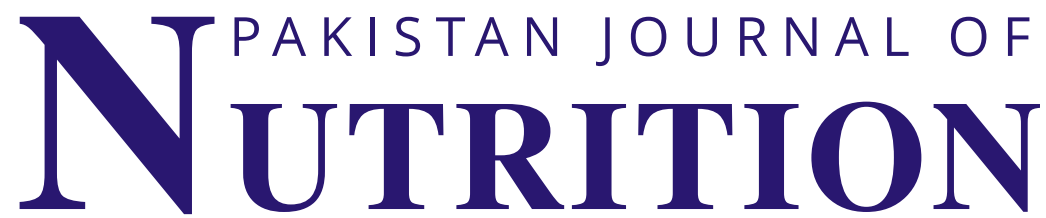

ANSI迫e佔

308 Lasani Town, Sargodha Road, Faisalabad - Pakistan Mob: +92 3003008585 , Fax: +92 418815544

E-mail: editorpjn@gmail.com 
Pakistan Journal of Nutrition 14 (12): 938-941, 2015

ISSN 1680-5194

(C) Asian Network for Scientific Information, 2015

\title{
Antioxidant and Antimicrobial Activities of Gambir (Uncaria gambir Roxb) Extracts and Their Application in Rendang
}

\author{
Sri Melia, Deni Novia and Indri Juliyarsi \\ Faculty of Animal Science, Andalas University, West Sumatera, Indonesia
}

\begin{abstract}
Gambir" (Uncaria gambir Roxb) used in this study was taken from 50 Kota Distric, West Sumatera, Indonesia, which was extracted by ethyl acetate. The antioxidant and antimicrobial activities of gambir extract were investigated. The antioxidant activities $\left(\mathrm{IC}_{50}\right)$ of gambir extracts which were evaluated by $\mathrm{DPPH}(1,1-$ dipheny/-2-picry/hydrazi) method, were $25.55 \mu \mathrm{g} / \mathrm{ml}$ and ascorbic acid was used as standard. Disc Diffusion Method was employed to evaluate the antimicrobial activity against some Gram-Positive bacteria (Staphylococcus aureus) and Gram-Negative (E. coli and Salmonella sp). Rendang was made with gambir extracts with level: $0,0.25,0.5,0.75$ and $1 \%$. The data obtained were processed statistically, if the treatment shows significant results $(p<0.05)$ then further tested by Duncan's Multiple Range Test (DMRT) with SPSS methods. The organoleptic test showed that addition of gambir extracts in Rendang was not significant $(p>0.05)$ and could extend the shelf-life of Rendang.
\end{abstract}

Key words: Gambir, antioxidant, antimicrobial and Rendang

\section{INTRODUCTION}

Gambir (Uncaria gambir Roxb) is one of Indonesia's export commodities, which grows mostly in West Sumatera. Gambir is one of commodities of industrial plants, which has a high economic value as well as a good prospect for farmers to produce supplies for foreign countries (Raut et al., 2015). Gambir, the dried leaf extracts from $U$. gambir is believed to have antioxidant properties which are attributed to the presence of tannins and condensed tannins (Apea-Bath et al., 2009).

Gambir contains polyphenol or catechins which work as antioxidant and antimicrobial. Catechins are the secondary metabolic group that is naturally produced by plants; it is also classified as a flavonoid under polyphenol compound. Antioxidant has an ability to grab the free radical from food by donating the hydrogen atom. The examples of antioxidant that share similar characteristic are phenolic (tocopherol, BHT, BHA, flavonoid, carotenoid and ascorbic acid). The antioxidants are naturally present in foods. They can be added or formed during processing. Antioxidant for food should be reasonable in cost, non toxic, stable, effective at low concentration and it should not change color, flavor and texture in food matrix (Choe and David, 2009). Rendang is a traditional food from Indonesia which has its own characteristics in ingredients and its processing. Beef and coconut milk are used as the main ingredients; that is why Rendang contains high percentage of fat. Those ingredients tend to flaw during the stirring that leads to the alteration in favor; the taste will be rancid due to oxidized fats. The breakage process on fat will recall the free radical which is dangerous if the contamination is consumed in large amount. Free radical tends to cause severe illness; but it can be avoided by adding antioxidant to the food. Antioxidant is a compound that functions to protect the food, especially if it contains a high percentage of fat, antioxidant will protect the food from oxidation such as oxidative rancidity. A natural antioxidant which can be used as a treatment is catechins which are taken from gambir.

Purpose of the research: The research aims to study antioxidant and antimicrobial activities of gambir extracts and their application in Rendang.

\section{MATERIALS AND METHODS}

Material of the research: The materials used in this research were beef that was sold in abattoir and the gambir which was taken from 50 Kota Distric.

The chemical compound used to analyze the proximate was taken from the Laboratory of Animal Science Andalas University, including etil asetat, ethanol, folinciocalteu reagent (Sigma chemical Co., St., Lois, Mo., U.S.A.), DPPH/2,2-diphenyl-1-picrylhydrazil or 1,1diphenyl-2-picrylhydrazitl (Sigma-Aldrich), $\mathrm{NaOH} \mathrm{0,1} \mathrm{N,}$ gallic acid, methanol, Plate Count Agar (Sigma-Aldrich), SSA (Sigma-Aldrich). The instrumentations used during the research were spectrophometer UV-Vis 1800 , filter paper Whatman, water bath and rotary evaporator.

Gambir extraction (Sandra et al., 2010): $1000 \mathrm{~g}$ dry gambir pollen was set in a dark bottle (2.5 litre) which was then added with $1000 \mathrm{ml}$ ethyl acetate; the mixture 
Pak. J. Nutr., 14 (12): 938-941, 2015

was stirred by swaying for $10 \mathrm{~min}$. It was macerated for $36 \mathrm{~h}$ (swayed 3 times a day) and then strained with filter paper; the waste was re-macerated for three times. The filtration was pureed by using rotary evaporator.

Processing Rendang (Novelina and Nurhaida, 1997): Preparing the formulation of ingredients: beef $1 \mathrm{~kg}, 3$ mature coconuts, red chili 150 gram, $65 \mathrm{~g}$ of red onion, $35 \mathrm{~g}$ of garlic, $20 \mathrm{~g}$ of galangal, $20 \mathrm{~g}$ of ginger, $5 \mathrm{~g}$ of turmeric, bay leaf 4 pieces, turmeric leaf 2 pieces, lemon grass and salt. Beef was cut into $2 \times 4 \times 5 \mathrm{~cm}$ and put in the boiled mixture of coconut milk and spices. The cooking process was around 3 hours. Then, catechin was added after the meat curry became oily; and the treatment was done randomly. It was heated until the curry became brownish. The Rendang sample was ready to observe based on its observation variable.

This experimental research applied randomized complete block design (RCBD) with 5 treatments and 4 repetitions. Rendang was made with gambir extract with level: $0,0.25,0.5,0.75$ and $1 \%$. The data obtained were processed statistically, if treatments showed significant results $(p<0.05)$, then they were tested by Duncan's Multiple Range Test (DMRT) with SPSS method.

\section{Analysis:}

- Antioxidant activity (Weecharangsan et al., 2006)

- Compounds and Phytochemical Screening of gambir extracts (Padmawinata and Iwang, 1987)

- $\quad$ Antimicrobial activity (Pratiwi, 2008)

- Shelf-life

- $\quad$ Organoleptic test (Rahayu, 2001)

\section{RESULTS AND DISCUSSION}

DPPH radical scavenging activity: $\mathrm{DPPH}$ scavenging methods have been commonly used to evaluate the antioxidant activity of compounds due to their simple, rapid, sensitives and reproducible procedures. DPPH radical scavenging activity parameters are used to determine the concentration which gives $50 \%$ effect equivalent antioxidant activity $\left(\mathrm{IC}_{50}\right)$. $\mathrm{DPPH}$ is a free radical which can react with compounds which can donate a hydrogen atom. The atom is useful for testing the activity of antioxidant components whose substances are present in an extract. Due to the presence of unpaired electrons, DPPH gives a strong absorption at $517 \mathrm{~nm}$. By the time, electron is paired with the presence of free-radical scavengers, the absorbance decreases stoichiometric, in accordance with the number of electrons that are taken. The existence of a solution of DPPH antioxidant compounds causes it to change from purple to yellow (Dehpour et al., 2009).

On Fig. 1 we can see a comparison between radical scavenging activity of gambir extract and ascorbic acid with a dilution series of 15.625 to $250 \mu \mathrm{g} / \mathrm{ml}$. The results

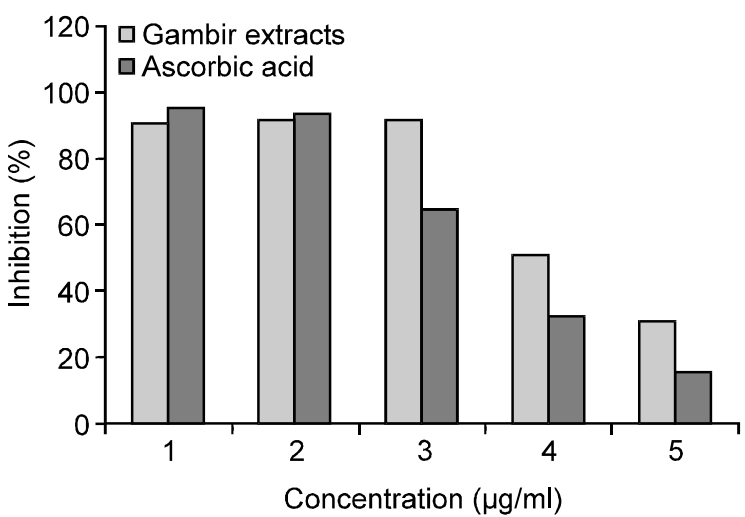

Fig. 1: DPPH radical scavenging activity of the gambir extract, compared with ascorbic acid, as standard

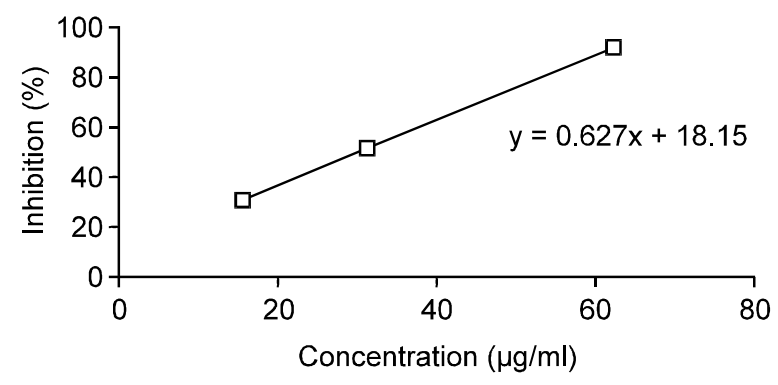

Fig. 2: Percent inhibition of DPPH against gambir extracts

show that the value of DPPH radical scavenging activity of gambir extract is higher than ascorbic acid. This means that the gambir extract has good activity as an antioxidant. Amir et al. (2012) reported that the effect of antioxidant on DPPH can be observed through their hydrogen donating ability.

Table 1 shows that \% inhibitions of the gambir extracts by serial dilution $15.625,31.25$ and $62.50 \mathrm{ug} / \mathrm{ml}$, respectively are $31.35,51.37$ and $92.24 \%$. Figure 2, indicates the linear regression curves of concentration of gambir extracts plotted against percent inhibition of $\mathrm{DPPH}(\mathrm{y}=0.627 \mathrm{x}+18.15)$. Furthermore, it was compared to a standard curve of ascorbic acid in order to obtain the value of DPPH with $\mathrm{IC}_{50} 25.55 \mu \mathrm{g} / \mathrm{ml}$. Based on this investigations, gambir extracts were categorized as having a very strong antioxidant strength ( $\left(\mathrm{C}_{50}<50\right.$ $\mu \mathrm{g} / \mathrm{ml}$ ) (Armala, 2009).

Compounds of gambir extracts: Table 2 shows the results of phytochemicals screening in Gambir extract containing flavonoids, phenolic and saponin.

The result of phytocemical screening, shows that the gambir extracts contain flavonoid, phenolic and saponin. Amir et al. (2012), reported that total phenolic and flavonoid contents found in gambir extract were 18.37 $\mathrm{mg}(\mathrm{GAE}) / \mathrm{g}$ and $5.82 \mathrm{mg}$ (RE)/g, respectively. Phenolic 
Pak. J. Nutr., 14 (12): 938-941, 2015

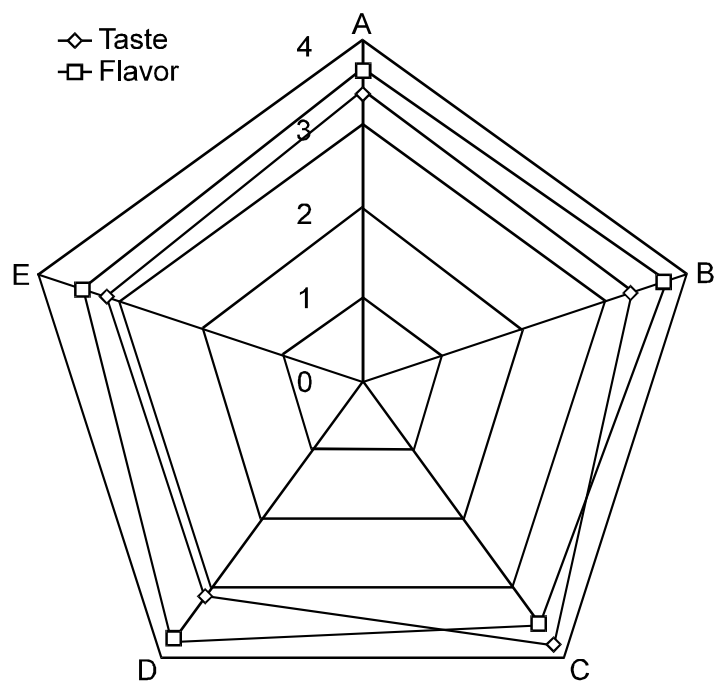

Fig. 3: Organoleptic test of Rendang

compounds are important constituents of plant and powerful chain breaking antioxidant. Phenolic compounds may contribute directly to antioxidant action. In the present study, total phenolic content of gambir extracts was measured by using the Folin-Ciocalteu reagent. The phenolic contents were found to be $271.875 \mathrm{mg}$ gallic acid equivalents (GAE/g dry weight).

Choe and David (2009), revealed that gambir contains polyphenol or catechins which function as antioxidant and antimicrobial. Catechins are the secondary metabolic group that is naturally produced by plants; it is also classified as a flavonoid under polyphenol compound Antioxidant has an ability to grasp the free radical from food by donating the hydrogen atom. The examples of antioxidant that share similar characteristics are phenolic (tocopherol, BHT, BHA, flavonoid, carotenoid and ascorbic acid).

Antimicrobial activity: Antimicrobial activity was measured through the growth of microorganisms to antimicrobial agents. The method used to measure antimicrobial activity is disc diffusion method. The disc with antimicrobial agent was placed on an agar, which has already planted with microorganisms. The clear area indicates the presence of microorganisms growth inhibition by an antimicrobial agent on the surface of an agar medium (Pratiwi, 2008).

Table 4, indicate that antimicrobial activity of gambir extract, against gram-negative bacteria ( $E$. coli and Salmonella sp) is greater than the gram-positive bacteria ( $S$. aureus).

Shelf-life of Rendang: Based on Table 5, it can be seen that the Rendang with the addition of Gambir extract $1 \%$ (E) has a longer shelf life (18 days) compared with Rendang without the addition of gambir extract $(A)$.
Table 1: Concentration of gambir extract and $\mathrm{IC}_{50}$ for DPPH inhibition

\begin{tabular}{lc}
\hline Concentration & Inhibition (\%) \\
\hline 62.50 & 92.24 \\
31.25 & 51.37 \\
15.625 & 31.35 \\
$\mathrm{IC}_{50}(\mu \mathrm{g} / \mathrm{ml})$ & 25.55 \\
\hline
\end{tabular}

Table 2: Phytochemicals in of Gambir extracts

\begin{tabular}{lc}
\hline Compounds & Gambir extracts \\
\hline Flavonoid & $(+)$ \\
Phenolic & $(+)$ \\
Saponin & $(+)$ \\
\hline
\end{tabular}

Table 3: Compounds of Gambir extracts

\begin{tabular}{ll}
\hline Compounds & Total \\
\hline Total fenol (mg GAE/g) & 272.875 \\
Cathecin $(\%)$ & 97.00 \\
Tannin $(\%)$ & 25.10 \\
\hline
\end{tabular}

Table 4: Antimicrobial activities of gambir extract

\begin{tabular}{lc}
\hline Bacteria & Antimicrobial activities $(\mathrm{cm})$ \\
\hline Staphylococcus aureus & $3.13 \pm 0.52$ \\
Escherecia coli & $1.56 \pm 0.49$ \\
Salmonella & $3.42 \pm 0.50$ \\
\hline
\end{tabular}

Table 5: Shelf-life Rendangs with addition gambir extract

\begin{tabular}{lc}
\hline Treatment & Shelf-life (days) \\
\hline A & $7.25 \pm 0.50^{\mathrm{a}}$ \\
B & $7.50 \pm 0.58^{\mathrm{a}}$ \\
C & $12.75 \pm 1.26^{\mathrm{b}}$ \\
D & $17.50 \pm 0.58^{\mathrm{c}}$ \\
$\mathrm{E}$ & $18.00 \pm 1.41^{\mathrm{c}}$ \\
\hline $\mathrm{a}-\mathrm{c}$ Mean with different superscript letters are significantly different \\
at $p<0.05$
\end{tabular}

Based on the analysis of variance, the addition of the Rendang gambir extract is significantly influential $(p<0.05)$. This is consistent with the results of the study in which the phytochemical analyses in gambir extract contains phenolic compounds, flavonoids and saponins, which act as antioxidants and antimicrobials. In addition, gambir extract also contains cathechin $97 \%$, Total phenol $272.875 \mathrm{mg} \mathrm{GAE} / \mathrm{g}$ and tannin $25.10 \%$. Gambir extract also has a fairly high antioxidant activity, by measuring $\mathrm{IC}_{50}(\mathrm{DPPH})$ was $25.55 \mu \mathrm{g} / \mathrm{ml}$.

Craft et al. (2012) revealed that the important application of antioxidant is their inclusion in food products as preservatives shelf-life and to maintain quality of food. Antioxidant in food depends on many factors, such as: the antioxidant location in food, interactions with other food constituents and condition of environment $(\mathrm{pH}$, ionic strength, hydrophilic and lipophilic balance).

Organoleptic test: The organoleptic test shows the taste and flavor of Rendang which was added by gambir extracts. The results of the research exhibits that the addition of gambir extracts at several levels of concentration produces the same value taste of Rendang. The level of acceptability was shown at score 
$1,2,3,4,5$. For more details, differences like power scores of each treatment can be seen in Fig. 3 .

Based on Fig. 3, it can be seen that the average value of Rendang taste with the addition of gambir extract ranges between 3.15-3.80. In this case, the level of preference Rendang with the addition of Gambir extract until 1.00\% level was liked. Results of analysis of variance show that the treatment effect is not significant $(p>0.05)$ to the value of Rendang flavor with the addition of Gambir extract. The addition of gambir extract is not significant ( $p>0.05$ ) to the value of Rendang aroma. It causes the gambir extract not to produce a distinctive aroma. So it does not affect the flavor of Rendang.

Conclusions: This study shows that gambir extract can be considered as preservative agents for both antioxidant and antimicrobial activities. The antioxidant activity $\left(\mathrm{IC}_{50}\right)$ of gambir extracts evaluated by $\mathrm{DPPH}(1,1-$ diphenyl-2-picrylhydrazif) method, was $25.55 \mu \mathrm{g} / \mathrm{ml}$ and ascorbic acid was used as standard. Antimicrobial activity of gambir extracts, against gram-negative bacteria ( $E$. coli and Salmonella $\mathrm{sp}$ ) is greater than the gram-positive bacteria ( $S$. aureus). Phytochemical screening shows that gambir extracts contain flavonoid, Phenolic and saponin. The organoleptic test shows that addition of gambir extracts in Rendang is not significant ( $p>0.05$ ) and could extend the shelf-life of Rendang.

\section{AKNOWLEDGEMENTS}

The financial support from Direktorat Jenderal Pendidikan Tinggi Kementrian Pendidikan dan Kebudayaan, Surat Perjanjian Pelaksanaan Hibah Penelitian Nomor: 030/SP2H/PL/DIT.LITABMAS/II/2015, Tanggal 5 Febuari 2015 was greatly appriciated.

\section{REFERENCES}

Amir, M., M. Mujeeb, A. Khan, K. Ashraf, D. Sharma and M. Aqil, 2012. Phytochemical analisys and in vitro antioxidant activity of uncaria gambir. Int. J. Green Pharm., 6: 67-72.

Apea-Bath, F.B., M. Hanafi, R.T. Dewi, S. Fajria, A. Darmawan, N. Artanti, P. Lotulung, P. Ngadymang and B. Minarti, 2009. Assesment of the DPPH and $\alpha$-glucosidase Inhibitory Potential of Gambir and Qualitative Identification of Major Bioactive Compound. J. Med. Plant Res., 3: 736-757.
Armala, M.M., 2009. Daya Antioksidan Fraksi Air Herba Kenikir (Cosmos caudatus H.B.K.) dan Profil KLT, Skripsi. Fakultas Farmasi Universitas Islam Yogyakarta.

Choe, E. and B.M. David, 2009. Mechanisme of Antioxidant in the Oxidation of Foods. Comprehensive Rev. in Food Sci. and Food Savety, 8: 345-358.

Craft, B.D., L. Adrian, A. Ryszard and B.P. Ronald, 2012. Phenol-Based Antioxidants and In Vitro Methods Used For Their Assesment. Cmprehensive Reviews in Food Science and Food Safety, 11: 148-173.

Dehpour, A.A., M.A. Ebrahimzadeh, N.N. Fazel and N.S. Mohammad, 2009. Antioxidant activity of methanol extract of ferula assafoetida and its essential oil composition. Grasas Accites, 60: 405-412.

Isnawati, A., R. Mariana, D.S. Ondri, Mutiatikum, W. Lucie and G. Retno, 2012. Bull. Penelt. Kesehat, 40: 201208.

Novelina and H. Nurhaida, 1997. Studi mengenai cita rasa Rendang yang diawetkan dengan cara sterilisasi dan pemberian antioksidan setelah dua bulan penyimpanan. Prosiding Seminar Tek, Pangan, pp: 169-174

Padmawinata, K. and dan S. I wang 1987. Metode fitokimia: penuntun cara modern menganalisa tumbuhan. Author. Harbone, J.B., Bandung: ITB

Pratiwi, S.T., 2008. Mikrobiologi farmasi. Erlangga, Jakarta.

Raut, A., Rahmawaty and Z.S. Amcilia, 2015. The condition of Uncaria gambir Roxb as one of important medical plants in North Sumatera Indonesia. Procedia Chem., 14: 3-10.

Rahayu, W.P., 2001. Penuntun Praktikum Penilaian Organoleptik. Fakultas Teknologi Pangan dan Gizi. Institut Pertanian Bogor. Bogor.

Sandra, A., D. Novia, A. Kasim and A. Nuridinar, 2010. Pengaruh Penambahan Katekin Gambir Sebagai katekin gambir terhadap Kualitas dan Nilai Organoleptik erndang Telur. Laporan Penelitian Dana DIPA-Unand. Padang.

Weecharangsan, W., P. Opanasopit, M. Sukma, T. Ngawhirumpat, U. Sotanaphun and P. Siripong, 2006. Antioxidative and Neuroprotective activities of Extracts from the Fruit Hull of Mangosteen (Garcinia mangostana. L). Medical Principles and Practise, 15: $281-287$. 